\title{
It's about the money
}

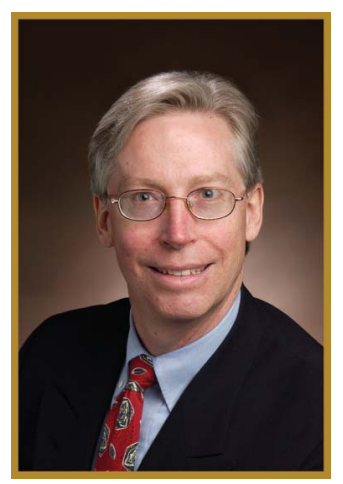

7 he old saying goes, "When they say it ain't about the money, it's about the money." Well, we have, finally, entered an era when everyone agrees, "It's about

L the money." In this issue of Neurology: Clinical Practice, we focus on costeffectiveness in the world of neurology. The article by Ho et al. outlines the utility of an MRI in patients with a first-time seizure and a negative head CT, noting that in $12 \%$ of these patients a lesion of importance may be discovered. Satya-Murti et al. describe the impact on the provider of use of a well-recognized but still somewhat new technology, vagal nerve stimulation. Callaghan et al. identify that $88 \%$ of diagnostic costs related to the common problem of peripheral neuropathy in the elderly are related to use of imaging and electrodiagnostics, and outline approaches to help contain costs. The article by Young et al. helps define issues to consider when reading cost-effectiveness articles, and the contribution of Cutter and Wang and the editorial by Satya-Murti put the scientific articles on cost-effectiveness into greater context. With the advent of the Affordable Care Act and Accountable Care Organizations, neurologists increasingly will be called upon to make economic decisions that have a real-life impact on their patients, and their own pocketbooks. We hope all these articles help our readers in making these complex decisions, and in future issues we will continue looking at the economic effects of diagnostic and treatment regimens from many points of view.
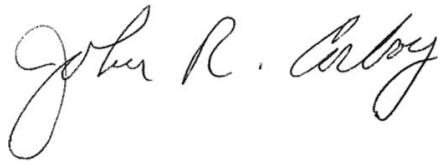

John R. Corboy, MD, FAAN 


\title{
Neurology ${ }^{\circ}$ Clinical Practice
}

\author{
It's about the money \\ Neurol Clin Pract 2013;3;365 \\ DOI 10.1212/CPJ.0b013e3182a9a508
}

This information is current as of October 14, 2013

\section{Updated Information \&} Services

Permissions \& Licensing

\section{Reprints}

including high resolution figures, can be found at:

http://cp.neurology.org/content/3/5/365.full.html

Information about reproducing this article in parts (figures,tables) or in its entirety can be found online at:

http://cp.neurology.org/misc/about.xhtml\#permissions

Information about ordering reprints can be found online: http://cp.neurology.org/misc/addir.xhtml\#reprintsus

Neurol Clin Pract is an official journal of the American Academy of Neurology. Published continuously since 2011, it is now a bimonthly with 6 issues per year. Copyright (C) 2013 American Academy of Neurology. All rights reserved. Print ISSN: 2163-0402. Online ISSN: 2163-0933.

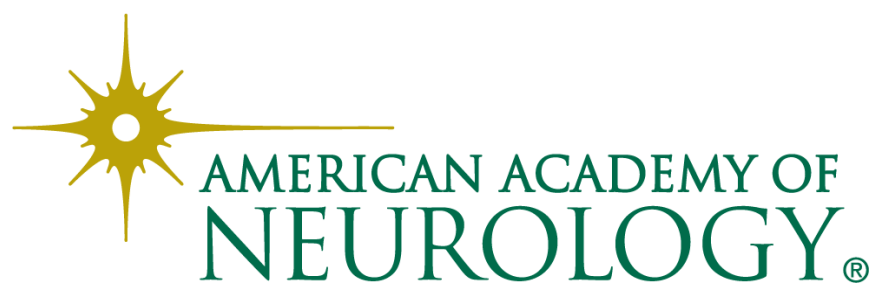

